\title{
Evaluation of malacosporean life cycles through transmission studies
}

\author{
S. Tops ${ }^{1}$, D. V. Baxa ${ }^{2}$, T. S. McDowell ${ }^{2}$, R. P. Hedrick ${ }^{2}$, B. Okamura ${ }^{1, *}$ \\ ${ }^{1}$ School of Animal and Microbial Sciences, University of Reading, Whiteknights, PO Box 228, Reading RG6 6AJ, UK \\ ${ }^{2}$ School of Veterinary Medicine, Department of Medicine and Epidemiology, 2108 Tupper Hall, University of California, \\ One Shields Avenue, Davis, California 95616, USA
}

\begin{abstract}
Myxozoans, belonging to the recently described Class Malacosporea, parasitise freshwater bryozoans during at least part of their life cycle, but no complete malacosporean life cycle is known to date. One of the 2 described malacosporeans is Tetracapsuloides bryosalmonae, the causative agent of salmonid proliferative kidney disease. The other is Buddenbrockia plumatellae, so far only found in freshwater bryozoans. Our investigations evaluated malacosporean life cycles, focusing on transmission from fish to bryozoan and from bryozoan to bryozoan. We exposed bryozoans to possible infection from: stages of $T$. bryosalmonae in fish kidney and released in fish urine; spores of T. bryosalmonae that had developed in bryozoan hosts; and spores and sac stages of B. plumatellae that had developed in bryozoans. Infections were never observed by microscopic examination of post-exposure, cultured bryozoans and none were detected by PCR after culture. Our consistent negative results are compelling: trials incorporated a broad range of parasite stages and potential hosts, and failure of transmission across trials cannot be ascribed to low spore concentrations or immature infective stages. The absence of evidence for bryozoan to bryozoan transmissions for both malacosporeans strongly indicates that such transmission is precluded in malacosporean life cycles. Overall, our results imply that there may be another malacosporean host which remains unidentified, although transmission from fish to bryozoans requires further investigation. However, the highly clonal life history of freshwater bryozoans is likely to allow both long-term persistence and spread of infection within bryozoan populations, precluding the requirement for regular transmission from an alternate host.
\end{abstract}

KEY WORDS: Myxozoa - Malacosporea - Proliferative kidney disease - Freshwater bryozoans · Transmission $\cdot$ Potential hosts $\cdot$ Life cycles

\section{INTRODUCTION}

The Phylum Myxozoa is comprised of about 55 genera and over 1300 species (Canning \& Okamura 2004) primarily parasitic in marine and freshwater fish. The phylum contains 2 classes: the Myxosporea (Bütschli 1881) and the Malacosporea (Canning et al. 2000, Kent et al. 2001). The former includes the majority of species, some of which cause economically important diseases, such as Myxobolus cerebralis, the causative agent of salmonid whirling disease (Bartholomew \& Reno 2002). Only some 25 myxosporean life cycles are known to date, and these involve annelid worms and fish as primary and secondary hosts (Okamura \& Canning 2003). Direct transmission has been demonstrated between fish (Diamant 1997, Redondo et al. 2002, Yasuda et al. 2002), but whether this process precludes the facultative incorporation of invertebrate hosts and represents a reduction in life cycle complexity is unknown (Canning \& Okamura 2004). Malacosporeans parasitise freshwater bryozoans (Bryozoa: Phylactolaemata) during at least part of their life cycle, but no complete malacosporean life cycle is known. 
Two species of malacosporean have been described so far. One is Buddenbrockia plumatellae (formerly Tetracapsula bryozoides; Canning et al. 2002), which occurs as both sac-like and vermiform stages in freshwater bryozoans (Monteiro et al. 2002, Okamura et al. 2002). The other member of the Class Malacosporea is Tetracapsuloides bryosalmonae (formerly Tetracapsula bryosalmonae; Canning et al. 2002). Only sac-like stages of $T$. bryosalmonae have been encountered in bryozoan hosts to date. $T$. bryosalmonae is the causative agent of salmonid proliferative kidney disease (PKD) (Anderson et al. 1999, Canning et al. 1999, Feist et al. 2001) and was, until recently, referred to as the PKX organism (Seagrave et al. 1980). The identification of bryozoans as hosts of $T$. bryosalmonae (Anderson et al. 1999) represented a breakthrough, as it finally determined the source of a disease which causes significant financial losses to fish farms and hatcheries of Europe and North America (Hedrick et al. 1993, Bromage 1999). PKD has also been implicated in the decline of wild salmonid populations in Switzerland (Wahli et al. 2002).

Freshwater bryozoans are sessile, colonial invertebrates that are common in both lotic and lentic habitats. They undergo prolific colony growth in summer and produce dormant, seed-like propagules (statoblasts) that overwinter and hatch into small colonies when favourable conditions return (Okamura \& Hatton-Ellis 1995). The freshwater bryozoan Fredericella sultana can also overwinter as colonies (Raddum \& Johnsen 1983, Gay et al. 2001). Malacosporeans develop into freely circulating sacs and active vermiform stages (Canning et al. 1996, 1999, 2002), which can be observed within the body cavity of their bryozoan hosts by inspection using a dissection microscope. Infective spores develop within sacs and worms. There is relatively little host specificity. Molecular data have identified Tetracapsuloides bryosalmonae infections in 5 bryozoan species (Anderson et al. 1999, Longshaw et al. 1999, Okamura \& Wood 2002), 2 of which have been confirmed as hosts through transmission studies (Feist et al. 2001, Gay et al. 2001). The vermiform stage of Buddenbrockia plumatellae has been found in 3 species (Canning et al. 2002, Monteiro et al. 2002), but the sac-like stages have only been found parasitising 1 bryozoan host-Cristatella mucedo (Okamura 1996, Canning et al. 2002).

Knowledge of the ecology, development and life cycles of malacosporeans is limited. Transmission studies from bryozoans to fish have confirmed bryozoans as true hosts of Tetracapsuloides bryosalmonae (Feist et al. 2001, Gay et al. 2001), but whether stages that develop in fish are capable of infecting new hosts has so far not been demonstrated. It is, however, known that PKD is not transmitted from fish to fish (Ferguson \& Ball
1979, D'Silva et al. 1984). In addition, the presence of $T$. bryosalmonae in bryozoan populations from sites devoid of salmonids (Okamura et al. 2001) suggests that these fish are, at best, facultative hosts. D. C. Morris et al. (2002a) and D. J. Morris et al. (2002) reported possible transmission of $T$. bryosalmonae and Buddenbrockia plumatellae from fish to bryozoans. However, these results may have reflected previous development of infection in bryozoans in the field, or PCR amplification of residual DNA that had adhered to bryozoans or of DNA from undetected, infected invertebrates.

Investigations into the pathogenesis of PKD have shown that Tetracapsuloides bryosalmonae has 2 developmental stages in salmonids (Hedrick et al. 1993). The extrasporogonic stage, found in the blood and kidney interstitium of infected fish, produces the chronic inflammatory response which is characteristic of the disease (Kent \& Hedrick 1986). The sporogonic stage is found in the kidney tubule lumen 2 to $3 \mathrm{wk}$ after the extrasporogonic stages are first observed. Sporogonic stages can persist in the kidney long after the recovery of the fish from clinical disease (Kent \& Hedrick 1986, Morris et al. 2000). Development of sporogonic stages in at least some fish hosts proceeds to the production of malacosporean-like spores containing 2 capsulogenic cells and 1 sporoplasm surrounded by 2 unstrengthened (soft) valve cells (Kent \& Hedrick 1986, Hedrick et al. 2004).

Certain observations have been cited as evidence that salmonids may be aberrant hosts for Tetracapsuloides bryosalmonae, including the severe inflammatory response of fish and incomplete spore development (Kent \& Hedrick 1986). However, before description of the Class Malacosporea (Canning et al. 2000), researchers expected final spore development to terminate in stages with typical hardened valves consistent with those observed in other myxosporeans. The possibility that fish should be considered as potential hosts is supported by the release of malacosporean-like spores in fish urine, as similar and functional spores of $T$. bryosalmonae develop in bryozoan hosts (Hedrick et al. 2004).

In view of our incomplete understanding of malacosporean life cycles, we undertook a series of studies to investigate potential routes of transmission of Tetracapsuloides bryosalmonae and Buddenbrockia plumatellae. In particular we focused on 2 unresolved issues: whether transmission can occur from fish to bryozoan and from bryozoan to bryozoan.

\section{MATERIALS AND METHODS}

We undertook the following types of transmission: (1) Fish to bryozoan: exposure of bryozoans to 
Tetracapsuloides bryosalmonae stages in fish kidney; (2) fish to bryozoan: cohabitation of bryozoans with fish infected with $T$. bryosalmonae; (3) bryozoan to bryozoan: exposure of bryozoans to $T$. bryosalmonaeinfected Fredericella sultana; (4) bryozoan to bryozoan: exposure of bryozoans to Buddenbrockia plumatellaeinfected Plumatella fungosa and Cristatella mucedo.

Below we describe the material used for transmission studies and the protocols for each type of transmission. Details of the individual trials are summarised in Table 1.

Bryozoans used as targets for infection. Three species of freshwater bryozoan (Fredericella sultana, Plumatella fungosa and Plumatella emarginata) were cultured in aquarium tank systems composed of smaller aquaria, housing the bryozoans, connected by recirculation to separate, larger aquarium tanks containing goldfish, according to the methods of Wood (1971) in conditions of constant light and temperature $\left(20^{\circ} \mathrm{C}\right)$. The tank systems were topped up with deionised water every 2 to $3 \mathrm{~d}$ when required and periodically seeded with water from a small, concrete-lined pond devoid of both bryozoans and fish with PKD. The incorporation of goldfish and periodic seeding with pondwater creates suitable environmental conditions and food, allowing bryozoans to be maintained indefinitely in culture. Bryozoans in such culture systems have been grown for many years (T. Wood pers. comm., S. Tops \& B. Okamura pers. obs.) with no sign of malacosporean infections being transferred between bryozoans and goldfish. This cultured bryozoan material provided potential target hosts for infection in our transmission studies and was regarded as infectionfree, as described below. The material was maintained in independent culture systems and was thus never in contact with infected bryozoan material collected from the field for use in transmission studies (described later).

Fredericella sultana: Transmission trials were performed using $F$. sultana material from several different derivations. The original material was collected from the Kennet and Avon Canal (51 $\left.24^{\prime} \mathrm{N}, 01^{\circ} 08^{\prime} \mathrm{W}\right)$ in October 2000. Colonies were induced to attach to surfaces of water-filled petri dishes or to submerged plastic discs (5.4 cm diameter) via their sticky, newly formed tips (Wood 1973, S. Tops pers. obs.). Subcultured material was derived by removing branches from original material established in culture, and inducing the branches to attach to new surfaces. Statoblasthatched material was obtained from statoblasts produced by subcultured F. sultana material. The statoblasts were placed in deionised water at $4^{\circ} \mathrm{C}$ and kept in the dark for a minimum period of $4 \mathrm{mo}$. They were then transferred to Petri dishes containing artificial pond water (Wood 1996) to induce hatching under ambient laboratory conditions (exposure to normal daylight period, $20^{\circ} \mathrm{C}$ ). The small colonies that emerged from statoblasts were grown in the culture system to provide material for trials. In keeping with the absence of Tetracapsuloides bryosalmonae during long-term monitoring of the source population (Tops \& Okamura 2003), infections were never observed in any F. sultana material in the culture system. In addition, PCR using T. bryosalmonae- and Buddenbrockia plumatellae-specific primers (see below) on portions of F. sultana colonies used as source material in transmission trials consistently provided negative results. This approach assumes that $T$. bryosalmonae is distributed throughout a colony and hence should be detected by screening portions of colonies by PCR, but there are no data to corroborate this assumption. Source material was only used during Trials $1 \mathrm{a}$ and $1 \mathrm{~b}$. For the remainder of the trials, statoblast-hatched F. sultana colonies were employed.

Plumatella fungosa: The source of all $P$. fungosa colonies was a single colony collected from Blenheim Palace Lake $\left(51^{\circ} 51^{\prime} \mathrm{N}, 01^{\circ} 23^{\prime} \mathrm{W}\right)$ in July 2000 . The material used in the transmission trials was the result of several generations of statoblast-derived colonies produced from this original colony, as described for Fredericella sultana above. No malacosporeans have ever been observed in this $P$. fungosa material in culture; however, as a further check that the material was uninfected, small portions of live bryozoans were cut from the stock material and subjected to PCR using Tetracapsuloides bryosalmonae- and Buddenbrockia plumatellae-specific primers (see below). Since none of these were positive for malacosporean infection, the material was deemed to be suitable for transmission studies. Severed branches were induced to attach to surfaces for transmission studies as described above.

Plumatella emarginata: P. emarginata colonies collected from Burghfield Lake, Berkshire $\left(51^{\circ} 26^{\prime} \mathrm{N}\right.$, $01^{\circ} 04^{\prime} \mathrm{W}$ ) in August 2002 released larvae in the laboratory. The larvae metamorphosed into small colonies on plastic discs which were placed in culture for onward growth, thus providing bryozoan colonies of larval origin for transmission studies. As a check that the material was uninfected by malacosporeans, small portions of colonies ( $\mathrm{n}=6$ colonies) were subject to PCR using Tetracapsuloides bryosalmonae- and Buddenbrockia plumatellae-specific primers (see below). Negative PCR results provided evidence that the material was suitable for transmission studies.

Sources of potential infection. Fish used for exposing bryozoans to infected kidney included rainbow trout Oncorhynchus mykiss obtained from a fish farm on the Kennet and Avon Canal, Berkshire, UK (Table 1: Trial 1a), wild brown trout Salmo trutta collected during routine survey work of trout populations 
conducted by the Environment Agency on the River Test, Hampshire, UK (Table 1: Trial 1b), and rainbow trout from a hatchery on the American River, California, USA (Table 1: Trial 1c). Fish used in cohabitation studies were naturally infected with Tetracapsuloides bryosalmonae and included rainbow trout from the American River Hatchery, California (Table 1: Trial 2b), and Chinook salmon Oncorhynchus tschawytscha from the Merced River Hatchery, California (Table 1: Trials 2a and 2c). Brown trout from Mount Shasta

Table 1. Summary of transmission trials, including identity of host and target species used in each trial, details of transmission including the exposure time of bryozoans to potential infection, the number (No.) of experimental (Exp) and control (Ctl) bryozoan colonies used in the trials (and subsequently subject to PCR), and the post-exposure culture period. Trials $1 \mathrm{a}$ to $3 \mathrm{~d}$ involved transmission with Tetracapsuloides bryosalmonae; Trials $4 \mathrm{a}$ and $4 \mathrm{~b}$ involved transmission with Buddenbrockia plumatellae

\begin{tabular}{|c|c|c|c|c|c|c|c|}
\hline $\begin{array}{l}\text { Trial } \\
\text { (Date) }\end{array}$ & Host species & Target species & $\begin{array}{c}\text { Transmission } \\
\text { details }\end{array}$ & $\begin{array}{c}\text { No. experimen } \\
\text { Fredericella } \\
\text { sultana }\end{array}$ & $\begin{array}{l}\text { al and control } \\
\text { Plumatella } \\
\text { fungosa }\end{array}$ & $\begin{array}{l}\text { olonies in trial } \\
\text { Plumatella } \\
\text { emarginata }\end{array}$ & $\begin{array}{l}\text { Culture } \\
\text { period }\end{array}$ \\
\hline $\begin{array}{l}1 \mathrm{a} \\
\text { (Oct 2000) }\end{array}$ & $\begin{array}{l}\text { Oncorhynchus } \\
\text { mykiss }\end{array}$ & Fredericella sultana & $\begin{array}{l}\text { Exposure to } \\
\text { macerated } \\
\text { kidney for } 24 \mathrm{~h}\end{array}$ & $\begin{array}{l}\text { Exp: } 6(0) \\
\text { Ctl: } 7(0)\end{array}$ & & & $54 \mathrm{~d}$ \\
\hline $\begin{array}{l}1 \mathrm{~b} \\
(\operatorname{Jan} 2001)\end{array}$ & Salmo trutta & $\begin{array}{l}\text { Fredericella sultana } \\
\text { Plumatella fungosa }\end{array}$ & $\begin{array}{l}\text { Exposure to } \\
\text { macerated } \\
\text { kidney for } 24 \mathrm{~h}\end{array}$ & $\begin{array}{l}\text { Exp: } 4(4) \\
\text { Ctl: } 4(0)\end{array}$ & $\begin{array}{l}\text { Exp: } 10(10) \\
\text { Ctl: } 10(10)\end{array}$ & & $37 \mathrm{~d}$ \\
\hline $\begin{array}{l}\text { 1C } \\
\text { (Jul 2002) }\end{array}$ & $\begin{array}{l}\text { Oncorhynchus } \\
\text { mykiss }\end{array}$ & $\begin{array}{l}\text { Fredericella sultana } \\
\text { Plumatella fungosa }\end{array}$ & $\begin{array}{l}\text { Exposure to } \\
\text { macerated } \\
\text { kidney for } 8 \mathrm{~h}\end{array}$ & Exp: 6 (4) & Exp: 1 (1) & & $14 \mathrm{~d}$ \\
\hline $\begin{array}{l}2 \mathrm{a} \\
\text { (Apr 2002) }\end{array}$ & $\begin{array}{l}\text { Oncorhynchus } \\
\text { tshawytscha }\end{array}$ & Fredericella sultana & $\begin{array}{l}\text { Cohabitation with } \\
\text { fish for } 80 \mathrm{~h}\end{array}$ & $\begin{array}{l}\text { Exp: } 20(9) \\
\text { Ctl: } 20(14)\end{array}$ & & & $22 \mathrm{~d}$ \\
\hline $\begin{array}{l}2 b \\
\text { (Apr 2002) }\end{array}$ & $\begin{array}{l}\text { Oncorhynchus } \\
\text { mykiss }\end{array}$ & Fredericella sultana & $\begin{array}{l}\text { Cohabitation with } \\
\text { fish for } 80 \mathrm{~h}\end{array}$ & Exp: 20 (12) & & & $22 \mathrm{~d}$ \\
\hline $\begin{array}{l}\text { 2c } \\
\text { (Jul 2002) }\end{array}$ & $\begin{array}{c}\text { Oncorhynchus } \\
\text { tshawytscha }\end{array}$ & $\begin{array}{l}\text { Fredericella sultana } \\
\text { Plumatella fungosa }\end{array}$ & $\begin{array}{l}\text { Cohabitation with } \\
\text { fish for } 19.5 \mathrm{~h}\end{array}$ & $\begin{array}{l}\text { Exp: } 10(8) \\
\text { Ctl: } 6(6)\end{array}$ & $\begin{array}{l}\text { Exp: } 1(0) \\
\text { Ctl: } 1(1)\end{array}$ & & $14 \mathrm{~d}$ \\
\hline $\begin{array}{l}2 \mathrm{~d} \\
\text { (Jul 2002) }\end{array}$ & Salmo trutta & $\begin{array}{l}\text { Fredericella sultana } \\
\text { Plumatella fungosa }\end{array}$ & $\begin{array}{l}\text { Cohabitation with } \\
\text { fish for } 19.5 \mathrm{~h}\end{array}$ & Exp: 10 (9) & Exp: $1(0)$ & & $14 \mathrm{~d}$ \\
\hline $\begin{array}{l}3 \mathrm{a} \\
\text { (Jun 2002) }\end{array}$ & Fredericella sultana & $\begin{array}{l}\text { Fredericella sultana } \\
\text { Plumatella fungosa }\end{array}$ & $\begin{array}{l}\text { Spores directed into } \\
\text { lophophores }(4 \mathrm{~h}) ; \\
\text { retention in spore } \\
\text { suspension }(20 \mathrm{~h})\end{array}$ & Exp: 5 (5) & Exp: $2(2)$ & & $30 \mathrm{~d}$ \\
\hline $\begin{array}{l}3 b \\
\text { (Oct 2002) }\end{array}$ & Fredericella sultana & $\begin{array}{l}\text { Fredericella sultana } \\
\text { Plumatella fungosa } \\
\text { Plumatella emarginata }\end{array}$ & $\begin{array}{l}\text { Spores directed into } \\
\text { lophophores }(4 \mathrm{~h}) ; \\
\text { retention of spore } \\
\text { suspension }(16 \mathrm{~h})\end{array}$ & Exp: 3 (3) & Exp: 1 (1) & Exp: 3 (3) & $33 \mathrm{~d}$ \\
\hline $\begin{array}{l}\text { 3c } \\
\text { (Jun 2002) }\end{array}$ & Fredericella sultana & Fredericella sultana & $\begin{array}{l}\text { Exposure to } \\
\text { shredded bryozoans } \\
\text { for } 135 \mathrm{~min}\end{array}$ & $\begin{array}{l}\text { Exp: } 3(2) \\
\text { Ctl: } 2(2)\end{array}$ & & & $30 \mathrm{~d}$ \\
\hline $\begin{array}{l}3 d \\
\text { (Aug 2003) }\end{array}$ & Fredericella sultana & Plumatella fungosa & $\begin{array}{l}\text { Exposure to } \\
\text { naturally released } \\
\text { spores for } 21 \mathrm{~d}\end{array}$ & & Exp: $10(10)$ & & $21 \mathrm{~d}$ \\
\hline $\begin{array}{l}\text { 4a } \\
\text { (Aug 2001) }\end{array}$ & Plumatella fungosa & Plumatella fungosa & $\begin{array}{l}\text { Spores directed into } \\
\text { lophophores }(4 \mathrm{~h}) ; \\
\text { retention in spore } \\
\text { suspension }(12 \mathrm{~h})\end{array}$ & & $\begin{array}{l}\text { Exp: } 2(0) \\
\text { Ctl: } 2(0)\end{array}$ & & $52 \mathrm{~d}$ \\
\hline $\begin{array}{l}4 \mathrm{~b}(\mathrm{i}) \\
\text { (Aug 2001) }\end{array}$ & Cristatella mucedo & $\begin{array}{l}\text { Fredericella sultana } \\
\text { Plumatella fungosa }\end{array}$ & $\begin{array}{l}\text { Spores directed into } \\
\text { lophophores }(4 \mathrm{~h}) ; \\
\text { retention in spore } \\
\text { suspension }(20 \mathrm{~h})\end{array}$ & $\begin{array}{l}\text { Exp: } 5(4) \\
\text { Ctl: } 5 \text { (5) }\end{array}$ & Exp: 5 (4) & & $60 \mathrm{~d}$ \\
\hline $\begin{array}{l}4 \mathrm{~b}(\mathrm{ii}) \\
\text { (Aug 2001) }\end{array}$ & Cristatella mucedo & $\begin{array}{l}\text { Fredericella sultana } \\
\text { Plumatella fungosa }\end{array}$ & $\begin{array}{l}\text { Exposure to } \\
\text { immature sacs for } \\
24 \mathrm{~h}\end{array}$ & Exp: $2(2)$ & Exp: 3 (2) & & $60 \mathrm{~d}$ \\
\hline $\begin{array}{l}4 \mathrm{~b}(\mathrm{iii}) \\
\text { (Aug 2001) }\end{array}$ & Cristatella mucedo & $\begin{array}{l}\text { Fredericella sultana } \\
\text { Plumatella fungosa }\end{array}$ & $\begin{array}{l}\text { Spores directed into } \\
\text { lophophores }(4 \mathrm{~h}) ; \\
\text { retention in spore } \\
\text { suspension }(20 \mathrm{~h})\end{array}$ & Exp: 2 (1) & Exp: 1 (1) & & $60 \mathrm{~d}$ \\
\hline
\end{tabular}


Hatchery, California, were hatched from eggs and maintained in well water at $15^{\circ} \mathrm{C}$ until intraperitoneally injected as in previous studies (Feist et al. 2001) with homogenised kidneys of Chinook salmon infected with extrasporogonic and sporogonic stages of T. bryosalmonae $6 \mathrm{wk}$ prior to the transmission trials (Table 1: Trial 2d).

Colonies of Fredericella sultana infected with Tetracapsuloides bryosalmonae collected from the River Cerne, Dorset, UK, provided material for bryozoan to bryozoan transmission (Table 1: Trials 3 a to $3 \mathrm{~d}$ ). The infection of a Plumatella fungosa colony by vermiform stages of Buddenbrockia plumatellae during a field experiment (Tops \& Okamura 2003) provided material for Trial 4a (Table 1), while infected colonies of Cristatella mucedo from Bonnerweiher, Bavaria, Germany, provided sac-like stages of B. plumatellae for Trial 4 b(i to iii) (Table 1).

Transmissions. Table 1 summarises details of the following transmission trials and should be referred to for information on the number of experimental and control bryozoan colonies used in trials. Note that PCR of portions of experimental colonies prior to exposure in trials served as an additional control unless otherwise specified. As previously mentioned, this method assumes that Tetracapsuloides bryosalmonae is distributed throughout a colony and hence can be detected by screening portions of colonies by PCR. Other controls are described below for individual trials.

(1) Fish to bryozoan. Exposure of bryozoans to infected fish kidney: Fish were collected from sites enzootic for PKD (Trials 1a to $1 \mathrm{C}_{i}$ Table 1) and transported to the laboratory. They were killed by a blow to the head, followed by severance of the spinal cord. For Trials $1 \mathrm{a}$ and $1 \mathrm{~b}$, approximately $27 \mathrm{~mm}^{3}$ of tissue was dissected from the posterior portion of the kidney and imprints were made for histological analysis to confirm infection by Tetracapsuloides bryosalmonae. For Trial $1 \mathrm{~b}$, kidney tissue was fixed in absolute ethanol and stored prior to PCR at $-20^{\circ} \mathrm{C}$. For Trial $1 \mathrm{C}$, wet mounts of the kidney material were prepared and examined according to Kent \& Hedrick (1986) to confirm the presence of sporogonic stages of $T$. bryosalmonae in kidney tubules.

For Trials $1 \mathrm{a}$ and $1 \mathrm{~b}$, the remaining kidney tissue was removed and placed in a minimal amount of $1 \mathrm{M}$ phosphate buffered saline (PBS) (Oxoid ${ }^{\mathrm{TM}}$ tablets; $\mathrm{pH}$ 7.3) on ice. Kidney material from all fish collected for each Trial was combined in a dish with a minimal amount of PBS, and disrupted using forceps. This macerated kidney material was added to an aerated tank containing colonies of Fredericella sultana and $16 \mathrm{l}$ of water from the bryozoan culture system. After $24 \mathrm{~h}$ the bryozoans were transferred to the culture system (unless otherwise specified, see below) and were then visually monitored every 2 to $3 \mathrm{~d}$, using a dissection microscope, for signs of infection. For Trial 1c, the kidney tissue was disrupted by passing it through a $150 \mu \mathrm{m}$ sieve with a minimal amount of PBS. Kidney homogenates were then combined as above and added to an aerated tank containing colonies of $F$. sultana and Plumatella fungosa, and $9.5 \mathrm{l}$ of well water. After $8 \mathrm{~h}$ the bryozoans were transferred to aquaria with water from a local pond at $15^{\circ} \mathrm{C}$ and visually monitored for signs of infection every 2 to $3 \mathrm{~d}$. Controls for Trial 1a consisted of $F$. sultana colonies similarly treated but not exposed to kidney homogenate, although PBS was added. Trials $1 \mathrm{~b}$ and $1 \mathrm{c}$ were constrained by availability of bryozoan material, and no separate colonies were available to act as controls. Consequently, for Trial $1 \mathrm{~b}$, portions of colonies collected prior to exposure to homogenate were subjected to PCR and served as controls. At the conclusion of the culture period, colonies in Trials $1 \mathrm{~b}$ and $1 \mathrm{c}$ were saved for PCR to assess potential cryptic infection (Tops \& Okamura 2003). Results of Trial 1a are based on visual inspection only.

(2) Fish to bryozoan. Cohabitation of bryozoans with infected fish: Bryozoans were exposed to fish recovering from PKD in cohabitation trials (see Trials 2a to $d_{i}$ Table 1) to determine whether sporogonic stages of Tetracapsuloides bryosalmonae that pass through the urinary tract of recovering fish are infective to bryozoans. Four exposures were carried out using naturally infected rainbow trout and Chinook salmon and artificially infected brown trout (see Table 1). The fish were maintained in flow-through tanks (133 l) supplied with well water at $15^{\circ} \mathrm{C}$.

Plastic discs $(5.4 \mathrm{~cm}$ diameter) with attached bryozoan colonies were randomly allocated positions within cylindrical plastic cages (Fig. 1). Twenty Fredericella sultana colonies were available for Trials 2a and $2 \mathrm{~b}$, and 10 colonies for Trials $2 \mathrm{c}$ and $2 \mathrm{~d}$. Only 2 Plumatella fungosa colonies were available for Trials $2 \mathrm{c}$ and $2 \mathrm{~d}$ (see Table 1). Each cage could hold a maximum of 10 discs with colonies. Bryozoans were exposed to fish for $16 \mathrm{~h} \mathrm{~d}^{-1}$ (Trial 2a and 2b) and $6.5 \mathrm{~h}$ $\mathrm{d}^{-1}$ (Trial 2c and 2d) over a period of 5 and $3 \mathrm{~d}$ respectively. In between fish exposure periods, bryozoans were returned to pond water to feed. This was deemed to be essential since no food was available in well water and it was important to ensure colonies did not degenerate before parasites might develop. For Trials $2 \mathrm{a}$ and $2 \mathrm{~b}$, bryozoans were cohabited with 50 fish per treatment in flow-through tanks (133 l) supplied with well water. For Trials $2 \mathrm{c}$ and $2 \mathrm{~d}$, bryozoans were cohabited with fish in buckets filled with aerated well water (19 l) in order to increase the likelihood of exposure to potential infective stages, since these would have been continuously lost in the flow-through 


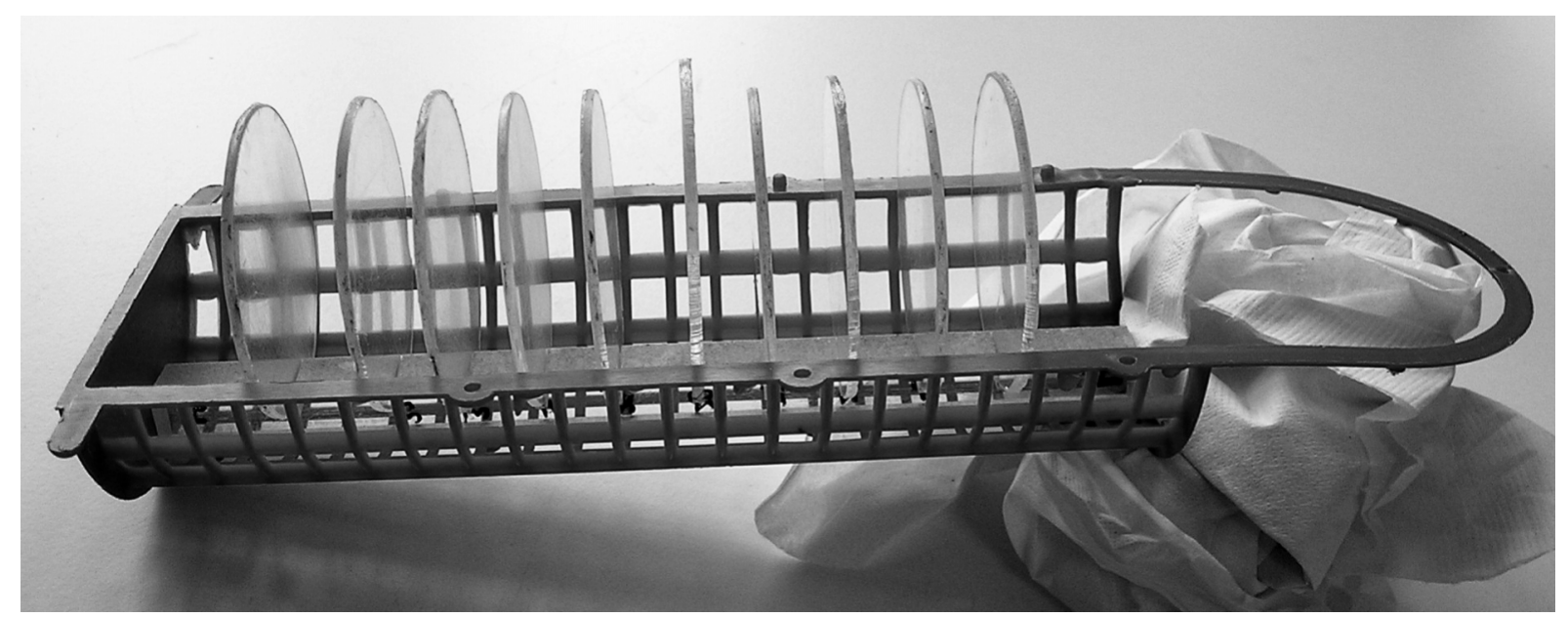

Fig. 1. Discs (5.4 cm diameter) and one half of the cage apparatus used in exposing bryozoans in Trials 2a to d and 3c. During trials bryozoans were enclosed within the fully assembled cage using cable ties, and were submersed in a downward facing position in experimental containers

arrangement used in Trials 2a and 2b. For Trials 2c and $2 \mathrm{~d}, 8$ fish were caught at random each day from a large group of infected individuals and were cohabited with the bryozoans in the bucket. At the end of each cohabitation period the fish were returned to the flowthrough system. Hence, different sets of fish were likely involved in the transmission study on different days. Bryozoans cohabited with a group of Chinook salmon hatched from eggs and reared in well water acted as controls for all trials.

After completion of exposure, the bryozoans were returned to the laboratory culture system and monitored for the presence of Tetracapsuloides bryosalmonae stages every 2 to $3 \mathrm{~d}$ using a dissection microscope. Regular observations of colonies allowed us to fix moribund bryozoans in absolute ethanol prior to their death to check for possible transmission of $T$. bryosalmonae by PCR. Nonetheless, some mortality occurred.

The presence of spores and sporogonic stages in the kidney tubules of fish was assessed post-exposure through histological examination of wet mounts as described earlier. Examination of a subset of fish in Trials $2 \mathrm{a}$ and $2 \mathrm{~b}$ indicated that extrasporogonic stages were present but sporogonic stages were rare. This prompted us to undertake Trials $2 \mathrm{c}$ and $2 \mathrm{~d}$ in hopes of including more mature stages. Examination of a subset of fish indicated that sporogonic stages were present in 3/10 fish in Trial 2c and 2/10 fish in Trial $2 \mathrm{~d}$ at low to moderate levels (based on subjective scoring by R. P. Hedrick, assessing the relative abundance of parasite stages as a result of familiarity gained during previous studies: Kent \& Hedrick 1986, Foott \& Hedrick 1987).
(3) Bryozoan to bryozoan. Exposure of bryozoans to Tetracapsuloides bryosalmonae infected Fredericella sultana: For Trial 3a, colonies of F. sultana were torn apart with forceps ('shredded') and observed with a dissection microscope. Sacs of $T$. bryosalmonae released by shredding were transferred to a small petri dish (with $10 \mu \mathrm{l}$ disposable microcapillary tubes) and burst open using a sterile, mounted needle to release spores. Concentrated spores were pipetted up into clean microcapillary tubes and wafted into the open lophophores of F. sultana and Plumatella fungosa colonies (see Table 1) from our laboratory stock, in separate petri dishes containing $20 \mathrm{ml}$ of culture water. The bryozoans were exposed to potential infection by spores in the petri dish for $24 \mathrm{~h}$. The water was agitated every 30 min for $4 \mathrm{~h}$ to re-suspend any viable spores which may have settled to the bottom of the dish and were thus unavailable for infection. After $24 \mathrm{~h}$, the bryozoans were transferred to the culture system and checked every 2 to $3 \mathrm{~d}$ for visual signs of infection. Colonies which survived culture for $30 \mathrm{~d}$ were saved for PCR as a further check on infection status. Colonies that appeared to be moribund were fixed for PCR at earlier dates prior to death.

A single colony of Fredericella sultana provided material for Trial 3b when it developed infection in culture $10 \mathrm{wk}$ after collection from the River Cerne, Dorset. Sacs were collected as for Trial 3a. Target colonies of $F$. sultana, Plumatella fungosa and P. emarginata (see Table 1) were exposed to spores for $20 \mathrm{~h}$, which were wafted into the lophophore every $30 \mathrm{~min}$ for $4 \mathrm{~h}$. Colonies were subsequently checked for visual signs of infection every d. After $33 \mathrm{~d}$ of culture the colonies were saved for PCR. 
For Trial 3c, Fredericella sultana colonies collected from the River Cerne were shredded (see above) and placed in a container with approximately $30 \mathrm{l}$ of water containing naïve rainbow trout and cage-enclosed target colonies of $F$. sultana for $135 \mathrm{~min}$, as part of a larger study (data not presented) on the transmission of Tetracapsuloides bryosalmonae to fish. Target bryozoans were then returned to culture and checked for visual signs of infection every $2 \mathrm{~d}$. After $30 \mathrm{~d}$ of laboratory culture the remaining live colonies were saved for PCR.

The development of persistent Tetracapsuloides bryosalmonae infections in colonies of Fredericella sultana (originally collected from the River Cerne) in 1 culture system and the coincident development of new Plumatella fungosa colonies that hatched from statoblasts in the same system allowed our fortuitous, unplanned Trial 3d. The P. fungosa colonies became established adjacent to heavily infected F. sultana colonies on the same petri dishes. The latter produced sacs over a prolonged period, and released mature spores and possibly sacs at a variety of developmental stages into the recirculating culture system. This should have resulted in the relatively continuous exposure to infection of the $P$. fungosa colonies during the period of spore viability. The $P$. fungosa colonies were maintained for $21 \mathrm{~d}$ alongside the infected $F$. sultana colonies, were checked for visual signs of infection every 2 to $3 \mathrm{~d}$, and were then fixed in absolute ethanol for PCR. There were no controls for this trial.

(4) Bryozoan to bryozoan. Exposure of bryozoans to Buddenbrockia plumatellae infected Plumatella fungosa and Cristatella mucedo: For Trial 4a, spore-filled vermiform stages of $B$. plumatellae infecting a colony of $P$. fungosa were collected by applying gentle external pressure to the infected portion of the bryozoan colony. Spores were collected and wafted into the open lophophores of uninfected $P$. fungosa colonies (see Table 1) in petri dishes as described above, and were resuspended once per hour for $4 \mathrm{~h}$. The $P$. fungosa colonies were exposed to spores for $16 \mathrm{~h}$ and then transferred to an aerated $2 \mathrm{l}$ aquarium with water from the culture system (from a system never exposed to infected bryozoan colonies) for $5 \mathrm{~d}$ prior to transfer to culture. Fifty percent of the volume in the 21 tank was replaced daily with fresh water from the culture system. The 2 colonies were maintained in culture for 52 $\mathrm{d}$, and were checked for visual signs of infection every 2 to $5 \mathrm{~d}$. Two uninfected, laboratory-reared $P$. fungosa colonies were used as controls. These were initially maintained in petri dishes filled with culture-system water. Deionised water was wafted into the lophophores and the water was agitated as described above. The colonies were then transferred to an aerated $2 \mathrm{l}$ aquarium containing water from the culture system never exposed to infected bryozoan colonies. After $5 \mathrm{~d}$ in the 21 aquarium, colonies were transferred to a culture system.

For Trial 4b(i) (see Table 1), spore-filled sacs of Buddenbrockia plumatellae were obtained by applying gentle external pressure to infected Cristatella mucedo colonies. Colonies of Fredericella sultana and Plumatella fungosa were exposed to the spores in an aerated 21 aquarium containing water from the culture system, as described above for Tetracapsuloides bryosalmonae. Spores were again resuspended every hour for $4 \mathrm{~h}$, and the total exposure time was $24 \mathrm{~h}$. Colonies were then placed into culture. Controls for this experiment were uninfected, laboratory-reared $F$. sultana colonies, which were maintained in $2 \mathrm{l}$ of aerated, culturesystem water. Deionised water was wafted into the lophophores and the water was agitated as described above. In addition, 20 C. mucedo colonies with immature sacs (lacking spores) were disrupted (Trial $4 \mathrm{~b}[\mathrm{ii}]$ ). The disrupted material was added to 21 of aerated culture water containing uninfected colonies of $F$. sultana and $P$. fungosa. The water was stirred every hour for $4 \mathrm{~h}$ to maintain the material in suspension. After $24 \mathrm{~h}$ the colonies were transferred to culture. Finally, 1 colony of $C$. mucedo with mature, spore-filled sacs of B. plumatellae was placed in $500 \mathrm{ml}$ culture water along with uninfected colonies of $F$. sultana and $P$. fungosa (Trial $4 \mathrm{~b}$ [iii]). The water was gently agitated every hour for $4 \mathrm{~h}$ to suspend any spores which may have been released by the infected $C$. mucedo colony. The passive release of sacs has been observed for both B. plumatellae (B. Okamura pers. obs.) and $T$. bryosalmonae (M. Longshaw pers. comm.). After $24 \mathrm{~h}$ of exposure, the bryozoans were transferred to culture. The bryozoans exposed to potential infection in Trials $4 \mathrm{~b}$ (i to iii) were maintained in culture for $60 \mathrm{~d}$, and were checked for visual signs of infection every 2 to 3 d. Appropriate culture conditions have not been identified for C. mucedo, so uninfected colonies of this species were not included in the study.

DNA extractions and PCR. DNA extraction of both bryozoan and fish material, that had been saved in absolute ethanol and stored at $-20^{\circ} \mathrm{C}$, was conducted using a standard CTAB ( $1 \% \mathrm{~N}$-cetyl N,N,N-trimethylammonium bromide)-Proteinase $\mathrm{K}$ method as described by Winnepenninckx et al. (1993), with the following modifications: (1) samples were stored at $-20^{\circ} \mathrm{C}$, (2) the samples were not ground in liquid nitrogen prior to extraction, (3) samples were suspended in $675 \mu \mathrm{l}$ preheated $\left(60^{\circ} \mathrm{C}\right) \mathrm{CTAB}$ buffer, and (4) all steps were carried out using $1.5 \mathrm{ml}$ plastic eppendorf tubes.

PCR amplification was conducted using either Tetracapsuloides bryosalmonae-specific primers (514F and $776 \mathrm{R}$, from D. C. Morris et al. 2002b) or primers we designed to specifically amplify Buddenbrockia plumatel- 
lae (BZ1 F: 5'-CGTAAGGCTTCAAGCGAAAG-3' and BZ2R: 5'-CGAGCGTTTTAAATGCAACA-3', product size 397 base pairs). The primers were not cross-reactive between the 2 species of parasite. Conditions for amplification were according to D. C. Morris et al. (2002b). Negative (adding ultrapure water as a template) and positive controls were included in all amplifications. An internal, competitive-standard mimic molecule developed by D. C. Morris et al. (2002b) was included as a means of checking the absence of PCR inhibition in assessing $T$. bryosalmonae infection. No internal competitive-standard was available for the assessment of B. plumatellae infections.

\section{RESULTS}

We obtained no evidence that the stages of Tetracapsuloides bryosalmonae that develop in fish and bryozoans caused infections in target bryozoan colonies, based on visual inspection of exposed colonies or by subsequent PCR. No infections were evident in any controls. The conclusion that the $T$. bryosalmonae stages found in bryozoans in our transmission trials are incapable of infecting bryozoans is bolstered by the finding that the naïve rainbow trout exposed to the parasite (Trial 3c) developed PKD; recipient bryozoans present during the same exposure period did not develop infections. Similarly, we obtained no evidence that either the sac-like or vermiform stages of Buddenbrockia plumatellae that develop in bryozoans are capable of producing new infections in bryozoans. The identity of the parasites used in transmission trials was confirmed by PCR using species-specific primers.

\section{DISCUSSION}

\section{Lack of transmissions}

Our studies provide evidence that the life cycles of the 2 malacosporean parasites known to date do not involve direct transmission from bryozoan to bryozoan, either by mature spores or by earlier sac stages. No infections resulted from exposing bryozoans to concentrated spores (Trials 3a to d, $4 \mathrm{a}, 4 \mathrm{~b}[\mathrm{i}$ and iii]), to immature sacs (Trial $4 \mathrm{~b}$ [ii]) or to long-term cohabitation with infected colonies releasing spores and possibly sacs at different stages of development (Trial 3d). The lack of direct transmission from bryozoan to bryozoan by exposure to immature sac stages suggests that there is no parallel in the life cycle of Tetracapsuloides bryosalmonae to the direct fish to fish transmission indicated for immature trophozoites of some myxosporeans (Diamant 1997, Redondo et al. 2002, Yasuda et al. 2002). The consistent absence of evidence for bryozoan to bryozoan transmissions for both T. bryosalmonae and Buddenbrockia plumatellae strongly indicates that such transmission is precluded in malacosporean life cycles.

Our trials also provided no evidence for transmission to bryozoans of Tetracapsuloides bryosalmonae stages that develop in fish. This result supports the suggestion that fish are abnormal hosts, a view supported by the intensity of the immune response mounted by fish to the presence of $T$. bryosalmonae (Kent \& Hedrick 1986) and by recent phylogeographic studies (Henderson \& Okamura 2004). The latter provide no indication that $T$. bryosalmonae was transferred to Europe during the introduction of rainbow trout through fisheries activities nor subsequently within Europe, a result that strikingly contrasts with the introductions of pathogens and parasites typically associated with aquaculture. For instance, such transfer is evident in the case of Myxobolus cerebralis, where introduction to North America from Europe in the 1950s rapidly established this myxozoan parasite in native populations of the obligate alternate host, the oligochaete worm Tubifex tubifex (Hoffman 1990). However, despite these caveats, the possibility of fish to bryozoan transmission requires further attention, as discussed below.

While the availability of material and variation in protocols meant that each study lacked replication, our consistent results are compelling. Indeed, a strength of the work is the incorporation of both a broad range of parasite stages and of potential new hosts. Thus, 3 bryozoan species were assayed as potential malacosporean hosts (Fredericella sultana, Plumatella fungosa and $P$. emarginata) and we utilised parasite stages from rainbow trout, brown trout and Chinook salmon, and the bryozoans $F$. sultana, $P$. fungosa and Cristatella mucedo. Also included were wild and farmed sources of fish, naturally and artificially infected fish, and fish from the UK and North America. In addition, we tested exposure to artificially and naturally released spores, and to parasitic sacs from infected bryozoan colonies. In total we assessed infection in 97 bryozoan colonies (a conservative estimate based on number of colonies subjected to PCR following post-exposure culture), and each bryozoan species tested as potential host material was sourced from different water bodies. Furthermore, transmission studies indicate that our stock material of $F$. sultana was susceptible to infection by Tetracapsuloides bryosalmonae in the field: colonies derived from our laboratory stock became infected when transplanted into the River Itchen, Hampshire, UK, while stock colonies in culture did not develop infections (Tops \& Okamura 2003). Stock material of $P$. fungosa was similarly sus- 
ceptible to infection by $T$. bryosalmonae in the River Itchen and was also infected by Buddenbrockia plumatellae in the Kennet and Avon Canal, Berkshire, UK (Canning et al. 2002, Tops \& Okamura 2003). These observations, together with the range of source localities for infected material, suggest that lack of infection in our transmission trials is not a result of using resistant host strains. It should also be pointed out that infection of bryozoans does not appear to be influenced by bryozoan maturity since $T$. bryosalmonae infections have been encountered in, e.g., small (young) colonies of Pectinatella magnifica (Okamura et al. 2001) and in established colonies of $F$. sultana which are producing statoblasts (S. Tops \& B. Okamura unpubl. data). Nonetheless, we offered a range of stages of potential new hosts, including branches of colonies derived from statoblasts (most trials), colonies derived from statoblasts (Trial 3d), and colonies derived from larvae ( $P$. emarginata in Trial $3 b$ ).

\section{Constraints of study}

Negative results such as ours are justifiably subject to criticism on methodological grounds. Thus, failure to close the life cycle of either malacosporean could be attributable to inappropriate conditions for transmission or for subsequent development of malacosporeans. The latter is unlikely since the development and persistence of infections in field-collected Fredericella sultana from the River Cerne in our laboratory culture system (Tops \& Okamura 2003, current study) demonstrate that the post-exposure culture conditions were appropriate for the development of Tetracapsuloides bryosalmonae in bryozoan hosts.

Constraints on transmission include the possibility that spore concentrations may have been too low to be effective or that mature infective stages were not present in the material used. We attempted to control for such contingencies given the limitations of each transmission trial. Thus, in our bryozoan to bryozoan transmission studies, we ensured physical contact between bryozoans and spores by wafting spores directly into bryozoan lophophores, and we exposed bryozoans to spores in small volumes of water to maximise spore concentrations. The inclusion of both bryozoans and fish in Trial 3c demonstrated that functional spores were indeed present at least in this trial, since the fish subsequently developed PKD (M. Longshaw \& S. Feist unpubl. data).

There is a greater possibility that transmissions of Tetracapsuloides bryosalmonae from fish to bryozoans were hampered by lack of mature infective stages, low concentrations of infective spores released in fish urine and short periods of exposure to allow bryozoans to feed. Unfortunately, it was not feasible to predict before the transmission trials whether fish were releasing spores. Post-transmission microscopic examination of kidney indicated that the fish used in Trials 2a and $2 b$ had not yet reached the stage of recovery from PKD dominated by release of spores from sporogonic stages, although some sporogonic stages were detected. Conducting these trials in flow-through systems may also have influenced transmission by greatly reducing spore concentrations. Microscopic examination indicated that a proportion of the fish used in Trials $2 \mathrm{c}$ and $2 \mathrm{~d}$ had sporogonic stages, and the conduction of these trials in buckets increased the possibility of spore contact with bryozoans. However, random selection of fish for trials and lack of knowledge about actual spore release in urine during trials hamper the interpretation of results. Similarly, infective stages may have been present in low concentration when bryozoans were exposed to macerated fish kidney. Filtering of the water used in transmission studies to determine concentrations of infective stages was not conducted. This would not have been feasible in the trials conducted in the flow-through systems. In addition, the soft, unprotected spores are likely to adhere and disintegrate on contact with filters, making their identification and quantification exceedingly difficult.

Despite the above caveats, there is some evidence that low concentrations of Tetracapsuloides bryosalmonae spores must be effective at achieving infection. Concentrations of spores released from bryozoans should be exceedingly low for much of the year given the generally low prevalence of infections in bryozoan populations (Okamura et al. 2001, Okamura \& Wood 2002, S. Tops \& B. Okamura unpubl. data). In addition, fish are routinely immunised by developing subclinical infections through exposure to waters enzootic for PKD in autumn, when water temperatures are decreasing (Longshaw et al. 2002) and when prevalence of infection in bryozoan populations is low (S. Tops \& B. Okamura unpubl. data). Furthermore, Feist et al. (2001) obtained transmission of $T$. bryosalmonae by cohabitation of fish with infected bryozoan material in a flowthrough system where the continuous loss of spores should have resulted in low concentration. Hedrick et al. (2004) estimated a maximum concentration of 120 T. bryosalmonae spores $\mathrm{ml}^{-1}$ fish urine, thus spores should become highly dilute upon release from fish in natural populations. These observations suggest that spores from both bryozoans and fish would have to be effective in contacting and infecting hosts at very low concentrations. An ability to achieve transmission at low concentration should be highly adaptive for dilute water-borne spores, and we would expect this to be true for all infective stages in the life cycle of $T$. bryosalmonae, be they stages achieving transmission 
from fish to bryozoans, from bryozoans to fish or from any other potential host.

Despite the expected effectiveness of spores at low concentrations, given the uncertainties associated with our fish to bryozoan transmissions, more work is required to assess this route of infection, particularly given the possible infection of bryozoans by malacosporeans through exposure to macerated fish kidney (D. C. Morris et al. 2002a) and to stages released from fish with PKD (D. J. Morris et al. 2002). However, even if such transmission is eventually demonstrated, it may only be facultative since infected bryozoans occur in sites lacking salmonids in Ohio and Michigan (Okamura et al. 2001). Furthermore, even if spores released by fish are demonstrated to be infective for bryozoans, it is difficult to envision how such spores could regularly infect bryozoan populations upstream from fish farms and hatcheries to cause the annual and massive PKD outbreaks that occur in many sites. For instance, very high prevalences of Tetracapsuloides bryosalmonae infections coincide with early seasonal growth of the bryozoan population just upstream from a fish farm which suffers PKD outbreaks on the River Cerne, Dorset (Longshaw et al. 1999, S. Tops \& B. Okamura unpubl. data). The bryozoan population and fish farm are no more than $6 \mathrm{~km}$ from the headwaters of the Cerne, and the only salmonids present in this stretch of water are a few farm escapees and a small population of brown trout (M. Longshaw pers. comm.). It seems unlikely that the high prevalences of infections (over $40 \%$; S. Tops \& B. Okamura unpubl. data) in dense stands of bryozoans on many willow roots could directly result from spores released by only a few fish. Another informative site is a salmonid hatchery in California (Hot Creek Hatchery) which experiences PKD outbreaks. Fish from the hatchery have rarely been collected upstream (probably due to difficulties in swimming through pipes) and rare cyprinids are the only resident fish in the short reach of stream between the spring source and the diversion of flow-through pipes to the hatchery (Okamura \& Wood 2002).

\section{Implications of study}

Our results imply that there may be another host incorporated in the life cycles of Tetracapsuloides bryosalmonae and Buddenbrockia plumatellae. Prior to the discovery of phylactolaemate bryozoans as hosts of the 'PKX' parasite, researchers screened many aquatic invertebrates and other fish species from sites enzootic for PKD in an attempt to locate the source of the infection. For instance, Morris et al. (1999) surveyed 35000 oligochaete worms. In another study, 60 to 80 species of aquatic invertebrates were investi- gated, including Gammarus sp., caddis flies, leeches and snails (Longshaw \& Feist 2000, M. Longshaw \& S. Feist unpubl. data cited in Feist et al. 2001). None of these invertebrates tested positive for the parasite, as determined by PCR investigation using specific primers. In addition, our culture systems contain many of the most cosmopolitan aquatic invertebrates, including chironomids, cladocerans, rotifers, oligochaetes, flatworms and snails, which have been introduced along with bryozoans brought in from the field. If any of these organisms were acting as hosts for $T$. bryosalmonae, we would anticipate that infections would eventually have developed within the long-term cultured bryozoans that were cohabited with infected bryozoans introduced from the field. Such infection has never been observed. However, it is possible that our culture conditions are unsuited to development in another host or that such a host was lacking.

So far there is no evidence that fish, other than salmonids and pike, act as hosts of Tetracapsuloides bryosalmonae (Hedrick et al. 1993, Adams \& Morris 1999). A number of other potential fish hosts have been investigated, but none have been identified (Adams \& Morris 1999). Furthermore, the broad diversity of habitats associated with PKD outbreaks and T. bryosalmonae infections in bryozoans provide evidence that no single fish can be an obligate host. T. bryosalmonae has been recorded from sites ranging from clear, cool streams to eutrophic lakes in North America, and the number of resident non-salmonids range from single (e.g. the rare cyprinid at Hot Creek Hatchery) to many species (Okamura et al. 2001). If fish hosts are obligate in the life cycle, this broad distribution of $T$. bryosalmonae suggests an unusual capacity to exploit a diversity of obligate fish hosts, although, as discussed below, the life cycle of bryozoans may complicate the interpretation of distributional data.

We anticipate that if another invertebrate or nonsalmonid fish host is utilised in the life cycle of Tetracapsuloides bryosalmonae, infection is likely to be patchy, as it is in bryozoan populations (Anderson et al. 1999, S. Tops \& B. Okamura unpubl. data), and that this has led to the lack of detection. The best chance of identifying what such a host might be rests in focusing on simple systems, as was done in the elucidation of the life cycle of the oyster parasite Marteilia refringens (Audemard et al. 2002). The simplest system for $T$. bryosalmonae would be the recirculating system in France (Gay et al. 2001), but PCR and transmissionbased investigations have so far failed to determine whether resident invertebrates in this system are incorporated in the life cycle of $T$. bryosalmonae (de Kinkelin et al. 1999, P. de Kinkelin \& D. J. Morris unpubl. data cited in Gay et al. 2001). If our transmission results are correct in demonstrating that transmis- 
sion is not direct from bryozoan to bryozoan, and further work confirms that salmonids are dead-end hosts, the search for an unknown host might once again become akin to looking for a needle in a haystack (Audemard et al. 2002).

\section{Bryozoan life cycles and cryptic malacosporean stages}

It is now clear that malacosporeans can persist for at least 2 to 3 mo as cryptic stages in the body wall of bryozoans prior to proliferating as sacs in the body cavity (Canning et al. 2002, Tops \& Okamura 2003). Myxosporeans appear to behave in a similar manner. Myxobolus cerebralis maintains persistent infections in oligochaetes characterised by periods of parasite dormancy and intermittent shedding of actinospores (Gilbert \& Granath 2001), while at low temperatures cryptic immature forms undergo cycles of replication but do not produce actinospores (El-Matbouli et al. 1999). These recent studies suggest that persistent cryptic infection is a general myxozoan feature and that cryptic infections of malacosporeans may be maintained indefinitely within bryozoan populations.

We predict that the life history of bryozoans plays an important role in the maintenance and spread of cryptic malacosporean infections without the necessity of regular transmissions from any other hosts. If cryptic stages proliferate as colonies grow, this would ensure that all regions of colonies become infected. Also, colonies of Fredericella sultana fragment as they become larger, and branches that drift downstream reattach (Wood 1973, S. Tops \& B. Okamura pers. obs.). Such fragmentation and reattachment could increase local prevalence of infection and introduce infected colonies elsewhere. Furthermore, as F. sultana itself overwinters as live colonies (Wood 1973, Raddum \& Johnsen 1983), cryptic infections can be maintained year-round in this species (Gay et al. 2001). Finally, if cryptic stages are present in dormant bryozoan statoblasts, infections could be passed to new colonies through hatching from statoblasts. All of these processes could promote long-term infections in bryozoan populations without the necessity of regular transmissions from any other hosts, thus explaining the high prevalences of mature infections in bryozoan populations early in the growing season (Longshaw et al. 1999, S. T.ops \& B. Okamura unpubl. data).

If cryptic stages of Tetracapsuloides bryosalmonae are capable of undergoing dispersal in bryozoan statoblasts, then the persistence of infections in some sites may simply be explained by colonisation through infected statoblasts and the subsequent spread of parasitism in the population through proliferation of para- sites within clonally reproducing bryozoan hosts. The growing body of evidence that waterfowl act as dispersal vectors of bryozoan statoblasts lends credence to this possibility. Such evidence includes ongoing gene flow amongst sites traversed by migratory waterfowl (Freeland et al. 2000), the presence of intact statoblasts in waterfowl digestive tracts and faeces (Figuerola et al. 2003), and the viability of some statoblasts following ingestion and excretion by waterfowl (Charalambidou et al. 2003). Such waterfowl-mediated dispersal of infected statoblasts, followed by the subsequent spread of parasitism in the bryozoan population, provides one explanation for the presence of infected bryozoan populations in sites lacking salmonids. Unravelling the ecology of early cryptic stages of malacosporeans, identification of the cues that promote proliferation of spore-producing sacs from these cryptic stages and investigating the clonal structure of bryozoan host populations are important areas for further research.

Acknowledgements. We thank A. Gómez for modified CTAB protocols, W. Cox and A. Thomas for providing infected fish, D. Butterworth, A. Mercer and S. Leach for access to bryozoan populations and provision of fish, Prof. M. El-Matbouli for laboratory space in Germany, S. Feist and M. Longshaw for allowing cohabitation of bryozoans with fish during transmission studies, and W. Lockwood for assistance in the maintenance of bryozoan colonies. The work was supported by the Natural Environment Research Council (NER/A/S/1999/ 00075) and the Department for the Environment Food and Rural Affairs (FC1112). B.O. was supported by a Research Fellowship from the Leverhulme Trust during a portion of the work and preparation of the manuscript.

\section{LITERATURE CITED}

Adams A, Morris DJ (1999) Antibody development, PCR and in-situ hybridisation. Annex 8 in: Proliferative kidney disease (PKD) in wild and farmed salmonids: draft report of the first workshop, 15-17 November 1999, CEFAS Laboratory, Weymouth, UK

Anderson CL, Canning EU, Okamura B (1999) 18S rDNA sequences indicate that PKX organism parasitizes Bryozoa. Bull Eur Ass of Fish Pathol 19:94-97

Audemard C, Le Roux F, Barnaud A, Collins C and 6 others (2002) Needle in a haystack: involvement of the copepod Paracartia grani in the life-cycle of the oyster pathogen Marteilia refringens. Parasitology 124:315-323

Bartholomew JL, Reno PW (2002) The history and dissemination of whirling disease. In: Bartholomew JL, Wilson JC (eds) Whirling disease: reviews and current topics. Am Fish Soc, Symp 29, Bethesda, MD, p 3-24

Bromage N (1999) Impact of PKD on the UK trout industry. Annex 2 in: Proliferative kidney disease (PKD) in wild and farmed salmonids: draft report of the first workshop, 15-17 November 1999, CEFAS Laboratory, Weymouth, UK

Bütschli O (1881) Myxosporidien. Zool Jahrb 1:162-164

Canning EU, Okamura B (2004) Biodiversity and evolution of the Myxozoa. Adv Parasitol 56:43-131 
Canning EU, Okamura B, Curry A (1996) Development of a myxozoan parasite Tetracapsula bryozoides gen. n. et sp. n. parasitic in the freshwater bryozoan Cristatella mucedo (Bryozoa: Phylactolaemata). Folia Parasitol 43:249-261

Canning EU, Curry A, Feist SW, Longshaw M, Okamura B (1999) Tetracapsula bryosalmonae n. sp. for PKX organism, the cause of PKD in salmonid fish. Bull Eur Ass Fish Pathol 19:203-206

Canning EU, Curry A, Feist SW, Longshaw M, Okamura B (2000) A new class and order of myxozoans to accommodate parasites of bryozoans with ultrastructural observations on Tetracapsula bryosalmonae (PKX Organism). J Eukaryot Microbiol 47:456-468

Canning EU, Tops S, Curry A, Wood TS, Okamura B (2002) Ecology, development and pathogenicity of Buddenbrockia plumatellae Schröder, 1910 (Myxozoa, Malacosporea) (syn. Tetracapsula bryozoides) and establishment of Tetracapsuloides n. gen. for Tetracapsula bryosalmonae. J Eukaryot Microbiol 49:280-295

Charalambidou I, Santamaría L, Figuerola J (2003) How far can the freshwater bryozoan Cristatella mucedo disperse in duck guts? Arch Hydrobiol 157:547-554

de Kinkelin P, Chilmonczyk S, Bleux C, Dorson M (1999) Proliferative kidney disease (PKD) in rainbow trout: 1 . epidemiological investigations in an infected recirculating system; 2. immune response of trout and protection against clinical infection. Annex 9 in: Proliferative kidney disease (PKD) in wild and farmed salmonids: draft report of the first workshop, 15-17 November 1999, CEFAS Laboratory, Weymouth, UK

Diamant A (1997) Fish-to-fish transmission of a marine myxosporean. Dis Aquat Org 30:99-105

D'Silva J, Mulcahey MF, de Kinkelin P (1984) Experimental transmission of proliferative kidney disease in rainbow trout, Salmo gairdneri Richardson. J Fish Dis 7:235-239

El-Matbouli M, McDowell TS, Antonio DB, Andree KB, Hedrick RP (1999) Effect of water temperature on the development, release and survival of the triactinomyxon stage of Myxobolus cerebralis in its oligochaete host. Int J Parasitol 29:627-641

Feist SW, Longshaw M, Canning EU, Okamura B (2001) Induction of proliferative kidney disease (PKD) in rainbow trout Oncorhynchus mykiss via the bryozoan Fredericella sultana infected with Tetracapsula bryosalmonae. Dis Aquat Org 45:61-68

Ferguson HM, Ball HJ (1979) Epidemiological aspects of proliferative kidney disease in rainbow trout, Salmo gairdneri Richardson in Northern Ireland. J Fish Dis 2:219-225

Figuerola J, Green AJ, Santamaría L (2003) Passive internal transport of aquatic organisms by waterfowl in Doñana, south-west Spain. Global Ecol Biogeogr 12:427-436

Foott JS, Hedrick RP (1987) Seasonal occurrence of the infectious stage of proliferative kidney disease (PKD) and resistance of rainbow trout, Salmo gairdneri Richardson, to reinfection. J Fish Biol 30:477-483

Freeland JR, Noble LR, Okamura B (2000) Genetic consequences of the metapopulation biology of a facultatively sexual freshwater invertebrate. J Evol Biol 13:383-395

Gay M, Okamura B, de Kinkelin P (2001) Evidence that the infective stages of Tetracapsula bryosalmonae for rainbow trout, Oncorynchus mykiss, are present throughout the year. Dis Aquat Org 46:31-40

Gilbert MA, Granath WO Jr (2001) Persistent infection of Myxobolus cerebralis, the causative agent of salmonid whirling disease, in Tubifex tubifex. J Parasitol 87: 101-107

Hedrick RP, MacConnell E, de Kinkelin P (1993) Proliferative kidney disease of salmonid fish. Ann Rev Fish Dis 3: $277-290$

Hedrick RP, Baxa DV, de Kinkelin P, Okamura B (2004) Malacosporean-like spores in urine of rainbow trout react with antibody and DNA probes to Tetracapsuloides bryosalmonae. Parasitol Res 92:81-88

Henderson M, Okamura B (2004) The phylogeography of salmonid proliferative kidney disease in Europe and North America. Proc R Soc Lond B 271:1729-1736

Hoffman GL (1990) Myxobolus cerebralis, a worldwide cause of salmonid whirling disease. J Aquat Anim Health 2: 20-37

Kent ML, Hedrick RP (1986) Development of the PKX myxosporean in rainbow trout Salmo gairdneri. Dis Aquat Org $1: 169-182$

Kent ML, Andree KB, Bartholomew JL, El-Matbouli M and 12 others (2001) Recent advances in our knowledge of the Myxozoa. J Eukaryot Microbiol 48:395-413

Longshaw M, Feist SW (2000) The agent of proliferative kidney disease (PKD) requires a bryozoan in its lifecyclestudies at CEFAS Weymouth on PKD and other myxozoans. Trout News 29:24-27

Longshaw M, Feist SW, Canning EU, Okamura B (1999) First identification of PKX in bryozoans from the United Kingdom-molecular evidence. Bull Eur Ass Fish Pathol 19: 146-148

Longshaw M, Le Deuff RM, Harris AF, Feist SW (2002) Development of proliferative kidney disease in rainbow trout, Oncorhynchus mykiss (Walbaum), following short-term exposure to Tetracapsula bryosalmonae infected bryozoans. J Fish Dis 25:443-449

Monteiro AS, Okamura B, Holland PWH (2002) Orphan worm finds a home: Buddenbrockia is a myxozoan. Mol Biol Evol 19:968-971

Morris DC, Morris DJ, Adams A (2002a) Molecular evidence of release of Tetracapsula bryosalmonae, the causative organism of proliferative kidney disease from infected salmonids into the environment. J Fish Dis 25:501-504

Morris DC, Morris DJ, Adams A (2002b) Development of improved PCR to prevent false positives and false negatives in the detection of Tetracapsula bryosalmonae, the causative agent of proliferative kidney disease (PKD). J Fish Dis 25:483-490

Morris DJ, Longshaw M, Adams A, Feist SW, Richards RH (1999) Is an oligochaete involved in the life cycle of PKX? In: Brit Soc Parasitol (BSP) Spring Meeting Abstracts, University of Warwick, p 32

Morris DJ, Adams A, Feist SW, McGeorge J, Richards RH (2000) Immunohistochemical and PCR studies of wild fish for Tetracapsula bryosalmonae (PKX), the causative organism of proliferative kidney disease. J Fish Dis 23: 129-135

Morris DJ, Morris DC, Adams A (2002) Development and release of a malacosporean (Myxozoan) from Plumatella repens (Bryozoa: Phylactolaemata). Folia Parasitol 49: $25-34$

Okamura B (1996) Occurrence, prevalence and effects of the myxozoan Tetracapsula bryozoides parasitic in the freshwater bryozoan Cristatella mucedo (Bryozoa: Phylactolaemata). Folia Parasitol 43:262-266

Okamura B, Canning EU (2003) Orphan worms and homeless parasites enhance bilaterian diversity. Trends Ecol Evol 18:633-639

Okamura B, Hatton-Ellis T (1995) Population biology of bryozoans: correlates of sessile, colonial life histories in freshwater habitats. Experientia 51:510-525

Okamura B, Wood TS (2002) Bryozoans as hosts for Tetracap- 
sula bryosalmonae, the PKX organism. J Fish Dis 25: 469-475

Okamura B, Anderson CL, Longshaw M, Feist SW, Canning EU (2001) Patterns of occurrence and 18S rDNA sequence variation of PKX (Tetracapsula bryosalmonae), the causative agent of salmonid proliferative kidney disease. J Parasitol 87:379-385

Okamura B, Curry A, Wood TS, Canning EU (2002) Ultrastructure of Buddenbrockia identifies it as a myxozoan and verifies the bilaterian origin of the Myxozoa. Parasitology 124:2115-223

Raddum GG, Johnsen TM (1983) Growth and feeding of Fredericella sultana (Bryozoa) in the outlet of a humic acid lake. Hydrobiologia 101:115-120

Redondo MJ, Palenzuela O, Álvarez-Pellitero P (2002) Experimental transmission of Enteromyxum scopthalmi (Myxozoa), an enteric parasite of turbot, Scophthalmus maximus. J Parasitol 88:482-488

Seagrave CP, Bucke D, Alderman DJ (1980) Ultrastructure of a haplosporean-like organism: the possible causative agent of proliferative kidney disease in rainbow trout. J Fish Biol 16:453-459

Tops S, Okamura B (2003) Infection of bryozoans by Tetra-

Editorial responsibility: Wolfgang Körting,

Hannover, Germany capsuloides bryosalmonae in sites endemic for salmonid proliferative kidney disease. Dis Aquat Org 57:221-226

Wahli T, Knuesel R, Bernet D, Segner H, Pugnovkin D, Burkhardt-Holm P, Escher M, Schmidt-Posthaus H (2002) Proliferative kidney disease in Switzerland: current state of knowledge. J Fish Dis 25:491-500

Winnepenninckx B, Backeljau T, De Wachter R (1993) Extraction of high molecular weight DNA from molluscs. Trends Gen 9:407

Wood TS (1971) Laboratory culture of freshwater Ectoprocta. Trans Am Microsc Soc. 90:229-231

Wood TS (1973) Colony development in species of Plumatella and Fredericella (Ectoprocta: Phylactolaemata). In: Boardman RS, Cheetham AH, Oliver WA Jr (eds) Development and function of animal colonies through time. Dowden, Hutchinson and Ross, Stroudsberg, PA, p $395-432$

Wood TS (1996) Aquarium culture of freshwater invertebrates. Am Biol Teach 58:46-50

Yasuda H, Ooyama T, Iwata K, Tun T, Yokoyama H, Ogawa K (2002) Fish-to-fish transmission of Myxidium spp. (Myxozoa) in cultured tiger puffer suffering from emaciation disease. Fish Pathol 37:29-33

Submitted: October 29, 2003; Accepted: March 12, 2004

Proofs received from author(s): July 22, 2004 